\title{
PERLINDUNGAN HUKUM TERHADAP AHLI WARIS YANG MEMPEROLEH WARISAN TANAH ABSENTEE
}

\author{
Novery Aditya Fakhrizal \\ Fakultas Hukum, Universitas Narotama, Surabaya \\ e-mail: fakhrizaladitya@gmail.com
}

\begin{abstract}
ABSTRAK
Waris merupakan permasalahan klasik yang dihadapi manusia sebagai subyek hukum, yang lebih menarik apabila warisan tersebut merubah hak milik yang seharusnya menjadi hak mutlak ahli waris menjadi absentee dikarenakan ahli waris tersebut berdomisili di luar kecamatan obyek warisnya tersebut. Hal ini diatur dalam Pasal 3 ayat (1) PP No. 224 Tahun 1961 jo Pasal 1 PP No. 41 Tahun 1964 yang menyatakan bahwa pemilikan tanah pertanian oleh orang yang bertempat tinggal di luar kecamatan tempat letak tanahnya dilarang. Oleh sebab itu ditetapkan, bahwa pemilik tanah pertanian yang bertempat tinggal di luar kecamatan tempat letak tanahnya tersebut wajib mengalihkan hak atas tanahnya kepada orang lain di kecamatan tempat letak tanah itu atau pindah ke kecamatan letak tanah tersebut kecuali jarak kecamatannya berbatasan antara pemilik dan tanahnya, sehingga masih dimungkinkan untuk mengerjakan tanah tersebut secara efisien sehingga produktivitasnya bisa lebih optimal. Ratio legis diberlakukannya peraturan pemerintah mengenai larangan kepemilikan tanah absentee di Indonesia didasarkan pada beberapa faktor, diantaranya faktor efektifitas dan faktor keadilan, sedangkan apabila perolehannya melalui waris, maka aturan mengenai absentee tersebut dapat menghilangkan hak waris.
\end{abstract}

Kata Kunci: Perlindungan Hukum, Waris, Absentee, Landreform.

\begin{abstract}
The question of inheritance is a classic problem faced by humans as the subject of law, which is more interesting if the inheritance changes the right of property which should be the absolute right of the heir to be absentee because the heirs are domiciled outside the subdistrict of the heirs object. This is regulated in Article 3 paragraph (1) of PP 224 of 1961 jo Article 1 of Government Regulation no. 41 of 1964 which states that the ownership of agricultural land by persons residing outside the sub-district where the location of the land is prohibited. Accordingly, it is stipulated that the owner of agricultural land residing outside the sub-district where the land is located shall transfer the right to his land to another in the sub-district of the land or move to the sub-district of the location of the land unless the distance of his sub-district is adjacent to the owner and the land, It is still possible to work the soil efficiently so that its productivity can be optimized. Ratio Legis of the enactment of government regulations regarding the prohibition of absenteeism in Indonesia on several factors, risk factors and factors of justice, while the requirement of inheritance, the requirement of absenteeism can eliminate one's inheritance rights. Keywords: Legal Protection, Inheritance, Absentee, Landreform.
\end{abstract}

\section{PENDAHULUAN}

Henny Tanuwidjaja ${ }^{1}$ menyatakan secara umum syarat pokok dari orang yang meninggalkan warisan atau peninggal warisan adalah orang yang bebas, mereka bebas untuk menentukan kemauannya. Hukum waris dapat dikatakan sebagai seluruh aturan yang menyangkut penggantian kedudukan harta kekayaan orang yang meninggal dunia. Ketertiban

\footnotetext{
${ }^{1}$ Henny Tanuwidjaja, Hukum Waris Menurut BW, Cet. I., Refika Aditama, Bandung, 2012, h. 5
}

hukum yang berkaitan dengan kepentingan publik mengharuskan pergantian kedudukan subyek hukum yang berhenti sebagai pendukung hak dan kewajiban hukum. Sedangkan para pihak yang mengambil alih semua hak dan kewajiban dinamakan ahli waris. Dalam hukum harta kekayaan para ahli waris pada hakekatnya melanjutkan pribadi pewaris sebagai individu atau bisa dikatakan para ahli waris mengisi 
kekosongan yang terjadi karena kematian, satu dan yang lain dalam konteks subyek-subyek hukum.

Fakta-fakta dalam perkara pewarisan yang secara potensial yang umumnya dapat mempertautkan perkara dengan suatu sistem hukum baik lokal maupun asing adalah: Status dan kedudukan benda atau harta peninggalan; Penentuan kapasitas hukum atau kemampuan hukum si pewaris; Penentuan validitas substansial dan/atau formal dari testamen. ${ }^{2}$

Dalam kehidupan nyata terdapat banyak fakta, yaitu segala sesuatu yang bener-benar ada. Di dalam ilmu hukum dikenal adanya dua macam fakta, yaitu fakta biasa dan fakta hukum. Fakta hukum adalah fakta yang diatur oleh hukum. ${ }^{3}$ Identifikasi fakta hukum merupakan suatu hal yang sangat esensial dalam praktik hukum karena bersangkut paut dengan hak dan kewajiban seseorang. ${ }^{4}$

Peristiwa hukum adalah peristiwa yang diatur oleh hukum. Dilihat dari segi isinya, peristiwa hukum dapat terjadi karena: pertama, Keadaan tertentu, misalnya orang yang sakit gila menyebabkan pengadilan memutuskan bahwa orang tersebut harus ditempatkan di bawah pengampuan; kedua, Kejadian alam, misalnya sebatang pohon disambar petir dan tumbang menimpa seorang pengantar surat yang sedang bertugas dengan mengendarai motor dan menewaskannya sehingga menimbulkan masalah asuransi dan tunjangan-tunjangan yang diterima oleh keluarganya; ketiga, Kejadian fisik yang menyangkut kehidupan manusia, yaitu keIahiran, kematian, dan usia tertentu yang menyebabkan seseorang dianggap cakap untuk melakukan tindakan hukum. ${ }^{5}$

Peristiwa hukum yang dimaksud dalam penulisan ini adalah peristiwa kelahiran dan kematian yang menyebabkan beralihnya hak atas tanah kepada ahli waris, sehingga ahli waris berhak atas harta kepunyaan pewaris termasuk memiliki tanah pertanian pewaris, apabila ahli waris berdomisili di luar daerah kecamatan dari obyek warisnya tersebut sehingga menyebabkan terjadinya perubahan status tanah garapan tersebut menjadi absentee, maka dalam jangka waktu 1 (satu) tahun sejak si

\footnotetext{
${ }^{2}$ Bayu Seto, Dasar-Dasar Hukum Perdata Internasional, Cet. III, Citra Aditya Bhakti, Bandung, 2001, h. 190

${ }^{3}$ Peter Mahmud Marzuki, Pengantar Ilmu Hukum, Kencana Prenada Media Group, Jakarta, 2012, h. 208.

${ }^{4}$ Ibid., h. 209.

${ }^{5}$ Peter Mahmud Marzuki, Op.Cit., h. 209-210.
}

pewaris meninggal dunia, ahli waris diwajibkan memindahkan hak atas tanah tersebut kepada orang lain yang tinggal di kecamatan di mana tanah tersebut berada atau ia wajib untuk pindah ke kecamatan letak tanah tersebut. Jangka waktu tersebut dapat diperpanjang oleh Menteri Agraria apabila terdapat alasan yang wajar atas sebidang tanah berdiri rumah tempat tinggal seseorang, maka pendapat setempat itulah yang menentukan, berapa luas yang dianggap halaman rumah dan berapa yang merupakan tanah pertanian. Dari hasil penelitian, terjadinya tanah absentee dapat dilakukan dengan 5 cara, yaitu: tanah absentee yang dimiliki karena pindah domisili; tanah absentee yang dimiliki karena permohonan hak milik; tanah absentee yang dimiliki karena pinjam nama; tanah absentee yang dimiliki karena jual beli tanah pertanian; tanah absentee yang dimiliki karena warisan.

Supriadi menyatakan bahwa program dari land reform tersebut antara lain: pertama, Pembatasan luas maksimum penguasaan tanah; kedua, Larangan pemilikan tanah secara absentee; ketiga, Redistribusi tanah-tanah yang selebihnya dari batas maksimum, tanah-tanah yang terkena larangan absentee, tanah-tanah bekas swapraja dan tanahtanah negara; keempat, Penetapan luas minimum pemilikan tanah pertanian disertai larangan untuk melakukan perbuatan-perbuatan yang mengakibatkan pemecahan pemilikan tanah-tanah pertanian menjadi bagian-bagian yang terlampau kecil. ${ }^{6}$

Adapun tujuan dari land reform antara lain: pertama, Pemerataan penguasaan atau pemilikan tanah pertanian untuk meratakan hasil produksinya; kedua, Mengakhiri sistem kapitalisme dan feodalisme dalam penguasaan, pemilikan dan pengusahaan di bidang keagrariaan; ketiga, Meningkatkan produksi pertanian; keempat, Meningkatkan taraf hidup petani dan rakyat pada umumnya; kelima, Menghilangkan jurang pemisah antara golongan (petani) kaya dan miskin. $^{7}$

\section{PERUMUSAN MASALAH}

Beranjak dari latar belakang sebagaimana sudah penulis uraikan di atas, maka dapat dirumuskan isu

${ }^{6}$ Supriadi, Hukum Agraria, Sinar Grafika, Jakarta, 2007, h. 203.

${ }^{7}$ R. Soeprapto, Undang-Undang Pokok Agraria dalam Praktek, Badan Peratanahan Nasional, Yogyakarta, 1986, h. 109. 
hukum atau permasalahan sebagai berikut, yaitu apa ratio legis diberlakukannya ketentuan mengenai tanah absentee di Indonesia, serta apakah larangan kepemilikan tanah absentee dapat menghilangkan hak waris.

\section{METODE PENELITIAN}

Penelitian ini merupakan suatu penelitian hukum normatif dengan pertimbangan analisa undang-undang Nomor 5 Tahun 1960 tentang Peraturan Dasar Pokok-Pokok Agraria (selanjutnya disingkat UUPA) serta peraturan perundangundangan lain yang mengatur tentang waris dan tanah absentee guna menemukan solusi dari hak pewaris yang mendapatkan warisan berupa tanah absentee, sehingga dapat dijadikan masukkan untuk menemukan teori baru kerangka produk hukum, khususnya dalam bidang waris dan pertanahan khususnya yang kepemilikannya absentee.

Dalam penulisan penelitian ini, pendekatan yang dipakai adalah pendekatan perundang-undangan atau statute approach, pendekatan sejarah atau historical approach, dan pendekatan konseptual atau conceptual approach.

Pertama, Pendekatan perundang-undangan atau statute approach adalah pendekatan dengan mendasarkan pada peraturan perundang-undangan yang berlaku yaitu UUPA serta peraturan perundangundangan lain yang mengatur tentang waris atau tanah absentee.

Kedua, Pendekatan sejarah atau historical approach dilakukan dengan menelaah latar belakang apa yang dipelajari dan perkembangan pengaturan mengenai isu hukum yang dihadapi. Telaah demikian diperlukan oleh peneliti untuk mengungkap filosofi dan pola pikir yang melahirkan ketentuan tentang program pemerintah yaitu land reform. Pendekatan historis ini diperlukan karena peneliti menganggap bahwa pengungkapan filosofis dan pola pikir ketika land reform itu dilahirkan, dan memang mempunyai relevansi dengan masa kini.

Ketiga, Pendekatan konseptual atau conceptual approach beranjak dari pandangan-pandangan dan doktrin-doktrin yang berkembang di dalam ilmu hukum. Dengan mempelajari pandanganpandangan dan doktrin-doktrin di dalam ilmu hukum, peneliti akan menemukan ide-ide yang melahirkan pengertian-pengertian hukum, konsep-konsep hukum, dan asas-asas hukum relevan dengan isu yang dihadapi. Pemahaman akan pandangan-pandangan dan doktrin-doktrin tersebut merupakan sandaran bagi peneliti dalam membangun suatu argumentasi hukum dalam memecahkan isu yang dihadapi.

\section{PEMBAHASAN}

Konflik agraria semakin marak belakangan ini dan kemungkinan akan terus mengalami peningkatan di masa datang, ada beberapa akar konflik yang paling mendasar. Masalah pertama, konflik agraria berakar dari sejarah yang panjang, di era kolonial banyak tanah (ulayat) milik rakyat yang tidak memiliki bukti kepemilikan sah diambil dengan cara paksa dan dijadikan perkebunan oleh Belanda. Proses nasionalisasi obyek-obyek kekuasaan Belanda pada era Orde Lama menempatkan tanah-tanah itu menjadi milik Negara Republik Indonesia. Seiring dengan tuntutan pembangunan, tanah rakyat semakin banyak dikuasai dan dimiliki negara pada era Orde Baru untuk kebutuhan-kebutuhan seperti perkebunan, pertambangan, daerah tujuan transmigrasi, pembangunan infrastruktur, dan fasilitas umum lainnya.

Dalam era demokrasi dan keterbukaan sekarang ini, rakyat kembali menggugat hak atas tanah (ulayat) mereka yang diambil oleh negara di masa lalu sehingga menyebabkan terjadinya sengketa atau konflik hukum. Ketika secara hukum lemah, rakyat memakai jalan pintas dengan melakukan demonstrasi, pemblokiran, penyerobotan, atau pendudukan lahan yang disengketakan. Dalam beberapa kasus, rakyat tidak bisa serta merta disalahkan dengan dalih penyerobotan lahan setelah datangnya perusahaanperusahaan dengan membuka bisnis di lahan yang terlantar, karena lahan yang terlantar tersebut bukan berarti tanpa pemilik, melainkan ada faktor lain yang menyebabkan rakyat tidak dapat menggarap tanah tersebut, seperti tidak memiliki modal, infrastruktur dasar, atau masalah teknis lainnya.

Menurut Bernhard Limbong, ${ }^{8}$ secara konseptual ada keterkaitan antara program reforma agraria dengan pengurangan kemiskinan, peningkatan produktifitas, ketahanan pangan, pembangunan dan kemandirian ekonomi, dan pelestarian lingkungan. Reforma agraria tidak hanya memajukan dan menyejahterakan

${ }^{8}$ Bernhard Limbong, Opini Kebijakan Agraria, Cetakan ke-1, Margaretha Pustaka, Jakarta, 2014, h. 73. 
masyarakat pedesaan, tetapi juga memperkuat ketahanan pangan dan pondasi perekonomian nasional. Tuntutan adanya reforma agraria dalam konteks pelestarian lingkungan merupakan tuntutan reformasi yang akan menguntungkan masyarakat hari ini maupun generasi-generasi mendatang.

\section{Undang-Undang Pokok Agraria dan Landreform}

Landreform bukan merupakan ide baru, kebijakan landreform sudah banyak diterapkan di negaranegara berkembang dan sukses mengangkat kualitas kehidupan perekonomian rakyat. Di Indonesia, landreform sudah dijalankan pada periode 1960-1965 sesuai amanat UUPA, UUPA dengan landreform sebagai salah satu muatan utama merupakan penjabaran dari Pasal 33 UUD 1945 yang oleh Bung Hatta disebut sebagai Politik Sosial Ekonomi Republik Indonesia, karena Landreform mampu mempromosikan keadilan sosial dan kesejahteraan, sebab kepemilikan tanah merupakan instrument yang efektif untuk meneruskan kekayaan kepada generasi berikutnya, jaminan untuk mengakses kredit, sumber keamanan pribadi dan sosial pada saat usia tua, kepemilikan tanah juga menjamin kelangsungan akses ke investasi jangka panjang dan sumber modal sosial setempat.

Landreform sebagai politik sosial ekonomi sukses di sejumlah negara, contohnya seperti di Jepang pada era 1948-1951 telah mendestribusikan 41 persen dari seluruh lahan tanaman kepada 81 persen dari jumlah keluarga yang tidak memiliki lahan. Pada periode yang sama, Korea Selatan meredistribusikan 44 persen dari lahan yang ada kepada 64 persen jumlah keluarga petani melalui program landreform. Di Indonesia sendiri program Landreform cukup berhasil dijalankan pada periode 1960-1965 dengan payung hukum UUPA dan UU No. 56 Tahun 1960 tentang Landreform. Namun, pelaksanaannya kemudian sangat lambat, termasuk pada masa orde baru melalui kebijakan transmigrasi dan perkebunan inti plasma. Sejak 1960 sampai tahun 2000, program Landreform terutama untuk lahan tanaman pangan tercatat $850.128 \mathrm{Ha}$ dari 26 juta Ha luas lahan tanaman pangan yang didistribusikan kepada 1,328 juta lebih keluarga petani yang tersebar di seluruh Indonesia.

\section{Alasan Filosofis Diberlakukannya Larangan Kepemilikan Tanah Secara Absentee}

Sebelum berlakunya UUPA, tanah-tanah berada di tangan segelintir oknum tuan-tuan tanah saja, sebagian besar rakyat Indonesia sebagai petani penggarap dan buruh tani saja. Untuk mengakhiri sistem pertanahan ini, pemerintah mengadakan program yang disebut dengan Landreform. Salah satu dari program Landreform adalah larangan kepemilikan tanah secara absentee. Dasar filosofi diadakannya larangan kepemilikan tanah pertanian secara absentee di dalam penjelasan umum UUPA dijelaskan bahwa pada asasnya tanah pertanian harus dikerjakan atau diusahakan secara aktif oleh pemiliknya sendiri.

Boedi Harsono mengatakan, tujuan adanya larangan ini adalah agar hasil yang diperoleh dari pengusaha tanah itu sebagian besar dapat dinikmati oleh masyarakat pedesaan tempat letak tanah yang bersangkutan, karena pemilik tanah akan bertempat tinggal di daerah penghasil. ${ }^{9}$

Gejala yang tampak adalah bahwa di satu pihak pemilik semula yang menggantungkan hidupnya pada produk pertanian justru terdepak dari tanahnya karena kebutuhan akan uang, dan pihak lain ada orang yang mempunyai kelebihan modal yang menginginkan penumpukan tanah sebagai sarana investasi. Maka yang terjadi adalah gejala menjadi buruh di atas tanah miliknya sendiri.

\section{Akibat Hukum Peralihan Hak Atas Tanah Karena Pewarisan yang Tidak Didaftarkan Pada Kantor Pertanahan}

Salah satu sebab berakhirnya kepemilikan seseorang atas tanah adalah karena kematian. Karena dengan adanya peristiwa hukum ini mengakibatkan adanya peralihan harta kekayaan dari orang yang meninggal, baik harta kekayaan material maupun immaterial kepada ahli waris orang yang meninggal tersebut. Dengan meninggalnya seseorang ini maka akan ada pewaris, ahli waris, dan harta kekayaan.

Pewaris adalah orang yang meninggal dunia dan meninggalkan harta kekayaan, sedangkan ahli waris adalah orang yang berhak atas harta kekayaan dari orang meninggal. Dan harta kekayaan yang

\footnotetext{
9 Boedi Harsono, Hukum Agraria Indonesia (Sejarah Pembentukan Undang-Undang Pokok Agraria, Isi dan Pelaksanaannya), Djambatan, Jakarta, 2008, h. 385.
} 
ditinggalkan bisa immaterial maupun material, harta kekayaan material antara lain tanah, rumah ataupun benda lainnya.

Hukum Waris adalah suatu hukum yang mengatur peninggalan harta seseorang yang telah meninggal dunia diberikan kepada yang berhak, seperti keluarga dan masyarakat yang lebih berhak. Hukum Waris yang berlaku di Indonesia ada tiga yakni: Hukum Waris Adat, Hukum Waris Islam, dan Hukum Waris Perdata. Setiap daerah memiliki hukum yang berbeda-beda sesuai dengan sistem kekerabatan yang mereka anut.

Peralihan hak milik atas tanah diatur dalam Pasal 20 ayat (2) UUPA yaitu hak milik dapat beralih dan dialihkan kepada pihak lain. Pengertian tentang kata "beralih" adalah suatu peralihan hak yang dikarenakan pemilik hak telah meninggal dunia maka haknya dengan sendiri menjadi beralih kepada ahli warisnya. Pasal 20 ayat (2) UUPA menyatakan bahwa hak milik atas tanah dapat beralih dan dapat dialihkan kepada pihak lain. Ada dua bentuk peralihan hak atas tanah atau hak milik yang dapat dijelaskan sebagai berikut: ${ }^{10}$

Pertama, Beralih adalah berpindahnya hak atas tanah atau hak milik dari pemegang haknya kepada pihak lain karena pemegang haknya meninggal dunia atau melalui pewarisan. Peralihan hak atas tanah atau hak milik ini terjadi karena hukum, artinya dengan meninggalnya pemegang hak (subyek), maka ahli warisnya memperoleh hak atas tanah atau hak milik tersebut. Di mana subyek dalam beralihnya hak atas tanah atau hak milik harus memenuhi syarat sebagai pemegang hak atas tanah atau hak milik.

Kedua, Dialihkan atau pemindahan hak adalah berpindahnya hak atas tanah atau hak milik dari pemegang (subyek) haknya kepada pihak lain karena suatu perbuatan hukum yang sengaja dilakukan dengan tujuan agar pihak lain tersebut memperoleh hak tersebut. Dalam dialihkan atau pemindahan hak disini, pihak yang mengalihkan atau memindahkan hak harus berhak dan berwenang memindahkan hak, sedangkan bagi pihak yang memperoleh hak harus memenuhi syarat sebagai pemegang hak atas tanah atau hak milik.

${ }^{10}$ Urip Santoso, Pendaftaran dan Peralihan Hak Atas Tanah, Kencana Prenada Media Group, Jakarta, 2010, h. 301.

\section{Bentuk Perlindungan Hukum Bagi Ahli Waris yang Peralihan Hak Atas Tanah Karena Pewarisannya Tidak Didaftarkan Pada Kantor Pertanahan}

Berbagai pengalaman historis telah membuktikan bahwa tanah sangat lengket dengan perilaku masyarakat bahkan tanah dapat menimbulkan masalah bila sendi-sendi perubahan tidak memiliki norma sama sekali. Betapa pentingnya tanah sebagai sumber daya hidup, maka tidak ada sekelompok masyarakatpun di dunia ini yang tidak memiliki aturan-aturan atau norma-norma tertentu dalam masalah pertanahan ini, penduduk bertambah, pemikiran manusia berkembang, dan berkembang pulalah sistem, pola, struktur dan tata cara manusia menetukan sikapnya terhadap tanah. Seiring dengan perubahan dan perkembangan pola pikir, pola hidup dan kehidupan manusia maka dalam soal pertanahan juga terjadi perubahan, terutama dalam hal pemilikan dan penguasaannya dalam hal ini tentang kepastian hukum dan kepastian hak atas tanah yang sedang atau yang akan dimilikinya.

Munculnya beberapa persoalan, baik mengenai pertambahan penduduk maupun perkembangan ekonomi, maka kebutuhan terhadap tanah dalam kegiatan pembangunan akan meningkat. Berdasarkan kenyataan ini, tanah bagi penduduk Indonesia dewasa ini merupakan harta kekayaan yang paling tinggi nilainya dan juga merupakan sumber kehidupan, maka dari itu jengkal tanah dibela sampai titik darah penghabisan apabila hak tanahnya ada yang mengganggu. Untuk menjaga jangan sampai terjadi sengketa maka perlu diadakan pendaftaran tanah. Sadar akan tugas dan kewajibannya itu maka pemerintah telah menetapkannya pada Pasal 19 UUPA yang pada ayat (1) menyatakan bahwa: Untuk menjamin kepastian hukum oleh pemerintah diadakan pendaftaran tanah di seluruh wilayah Republik Indonesia menurut ketentuan-ketentuan yang diatur dengan Peraturan Pemerintah. Selanjutnya pada ayat (2) memberikan rincian bahwa pendaftaran tanah yang disebut pada ayat (1) tersebut meliputi: Pertama, Pengukuran, pemetaan, dan pembukuan tanah; Kedua, Pendaftaran hak-hak atas tanah dan peralihan hak-hak tersebut; Ketiga, Pemberian surat tanda bukti hak yang berlaku sebagai alat bukti yang kuat. Sebagai implementasi dari Pasal 19 ayat (1) dan (2) ini maka dikeluarkanlah Peraturan 
Pemerintah di bidang Pendaftaran Tanah yaitu Peraturan Pemerintah No. 10 Tahun 1961 mengenai Pendaftaran Tanah. Pendaftaran tanah dimaksud dijejaskan oleh PP No. 10 Tahun 1961 pada Pasal 2 ayat (1) yaitu harus dilakukan desa demi desa atau daerah-daerah yang setingkat dengan itu; Keempat, Dengan melihat konsepsi Pasal 19 ayat (1) dan (2) UUPA serta Pasal 2 ayat (1) PP No. 10 tahun 1961 tersebut di atas, maka kita dapat mengetahui bahwa pendaftaran tanah adalah perlu demi terciptanya kepastian hukum dan kepastian hak atas tanah. Dalam pelaksanaan pendaftaran ini, pemerintah akan melaksanakan secara sederhana dan mudah dimengerti dan secara berangsur-angsur. Konsepsi logis dari semua itu adalah ayat (2c) Pasal 19 UUPA yaitu akan diberikan tanda bukti hak/surat bukti hak, di mana surat-surat bukti hak tersebut akan berlaku sebagai alat pembuktian yang kuat. Inilah fungsi pokok sebenarnya dari pendaftaran tanah.

Tujuan pendaftaran tanah adalah memberikan kepastian hukum dan perlindungan hukum terhadap hak atas tanah. Pendaftaran Tanah adalah tugas dan beban pemerintah akan tetapi untuk mensukseskannya atau keberhasilannya sangat tergantung pada partisipasi aktif atau peranan masyarakat terutama pemegang hak. Sistem pendaftaran tanah yang dianut oleh PP No. 10 Tahun 1961 adalah Sistem Negatif. Sistem ini disempurnakan atau dikembangkan oleh PP No. 24 Tahun 1997 adalah asas negatif mengandung unsur positif, menghasilkan surat tanda bukti hak yang berlaku sebagai alat pembuktian yang kuat.

Pendaftaran peralihan hak karena pewarisan diwajibkan dalam rangka memberikan perlindungan hukum kepada para ahli waris dan demi ketertiban tata usaha pendaftaran tanah, agar data yang tersimpan dan disajikan selalu menunjukkan keadaan yang mutakhir. Sehubungan dengan pemberian kepastian hukum mengenai hak-hak atas tanah, baik mengenai subjek maupun objeknya, maka pemerintah mengharuskan dilakukan pengumuman mengenai hak-hak atas tanah, yang meliputi: Pertama, Pengumuman mengenai subjek yang menjadi pemegang hak yang dikenal dengan sebagai asas publisitas dengan maksud agar masyarakat luas dapat mengetahui tentang subjek dan objek atas satu bidang tanah. Adapun implementasi dari asas publisitas ini adalah dengan mengadakan pendaftaran tanah. Kedua, Penetapan mengenai letak, batasbatas, dan luas bidang-bidang tanah yang dipunyai seseorang atas sesuatu hak atas tanah, dikenal sebagai asas spesialitas daan implementasinya adalah dengan mengadakan Kadaster.

Dengan demikian, maka seseorang yang hendak membeli suatu hak atas tanah tidak perlu melakukan penyelidikan sendiri, karena keterangan mengenai subyek dan objek atas suatu bidang tanah dapat diperoleh dengan mudah pada instansi pemerintah yang ditugaskan menyelenggarakan Pendaftaran Tanah.

Pelaksanaan pendaftaran tanah sebagaimana yang diatur oleh PP No. 10 Tahun 1961 belum berjalan efektif, hal ini selain sasaran utamanya atau daerah yang diutamakan adalah daerah-daerah perkotaan, juga menyangkut tata cara, administrasi dan biaya yang harus ditanggung oleh masyarakat pemegang hak atas tanah sangatlah berat dirasakan oleh masayarakat pemegang hak atas tanah serta sosialisasi terhadap pelaksanaan PP itu sendiri belum maksimal. Dengan kondisi tersebut maka tujuan pendaftaran tanah belum tercapai.

Objek pendaftaran tanah ini bila dikaitkan dengan sistem pendaftaran tanah maka menggunakan sistem pendaftaran tanah bukan pendaftaran akta, karena sistem pendaftaran tanah ditandai atau dibuktikan dengan adanya dokumen Buku Tanah sebagai dokumen yang memuat data yuridis dan data fisik yang dihimpun dan disajikan serta diterbitkannya sertifikat sebagai surat tanda bukti hak yang didaftar, sedangkan pendaftaran akta, yang didaftar bukan haknya, melainkan justru aktanya yang didaftar, yaitu dokumen-dokumen yang membuktikan diciptakannya hak yang bersangkutan dan dilakukannya perbuatanperbuatan hukum mengenai hak tersebut kemudian hari.

PP No. 24 Tahun 1997 berefek mengakibatkan meningkatnya kegiatan pendaftaran tanah, akan tetapi kegiatan ini perlu ditingkatkan dengan mencari solusi yang efektif agar tujuan hakiki dari pendaftaran tanah terutama bagi tanah yang akan didaftar secara sistematis dan sporadik dapat tercapai.

Sistem pendaftaran tanah yang dianut oleh PP No. 10 Tahun 1961 adalah Sistem Negatif. Sistem ini disempurnakan atau dikembangkan oleh PP No. 24 Tahun 1997 adalah asas negatif mengandung unsur 
positif, menghasilkan surat tanda bukti hak yang berlaku sebagai alat pembuktian yang kuat.

Pemerintah harus terus mencari cara dan sistem dalam rangka optimalisasi tujuan pendaftaran tanah terutama mengenai asas sederhana, aman dan terjangkau, sehingga golongan ekonomi lemah pun dapat termotifasi untuk mendaftarkan tanahnya terutama secara sistematis dan sporadik, walaupun saat ini sudah ada program Larasita yang lebih mendekatkan pada pelayanan dan bantuan biaya.

Apabila dilihat dari tujuan pendaftaran tanah baik melalui PP No. 10 Tahun 1961 maupun No. 24 Tahun 1997 maka status kepemilikan hak atas tanah bagi Warga Negara Indonesia akan terjamin dan akan tercipta suatu kepastian baik mengenai, subjeknya, objeknya maupun hak yang melekat diatasnya termasuk dalam hal ini peralihan hak atas tanah. Hanya saja, Kantor Pertanahan harus lebih aktif lagi mensosialisasikan kegiatan pendaftaran tanah baik mengenai tata cara, prosedur maupun biayanya serta pentingnya pendaftaran tanah ini bagi pemegang hak. Serta lebih penting lagi Kantor Pertanahan harus senantiasa melakukan pemutakhiran data tanah agar tidak terjadi overlapping dalam pemberian haknya atau pendaftaran haknya yang dapat menimbulkan masalah hukum yaitu sengketa/ perkara yang disebabkan oleh adanya sertifikat ganda atau sertifikat palsu. Kantor Pertanahan haruslah senantiasa memutakhirkan datanya terutama pembuktian sertifikat sebagai tanda bukti hak dimuat dalam Pasal 32 PP No. 24 Tahun 1997, yaitu: Pertama, Sertifikat merupakan surat tanda bukti hak yang berlaku sebagai alat pembuktian yang kuat mengenai data fisik dan data yuridis yang termuat di dalamnya, sepanjang data fisik dan data yuridis tersebut sesuai dengan data yang ada dalam surat ukur dan buku tanah yang bersangkutan. Kedua, Dalam atas hak suatu bidang tanah sudah diterbitkan sertifikat secara sah atas nama orang atau badan hukum yang memperoleh tanah tersebut dengan itikad baik dan secara nyata menguasainya, maka pihak lain yang merasa mempunyai hak atas tanah itu tidak dapat lagi menuntut pelaksanaan hak tersebut apabila dalam waktu 5 tahun sejak diterbitkannya sertifikat itu tidak mengajukan keberatan secara tertulis kepada pemegang sertifikat dan kepala kantor pertanahan yang bersangkutan ataupun tidak mengajukan gugatan ke pengadilan mengenai penguasaan tanah atau penerbitan sertifikat.

Ketentuan Pasal ayat (1) PP No. 24 Tahun 1997 merupakan penjabaran dari ketentuan Pasal 19 ayat (2) huruf c, Pasal 23 ayat (2), Pasal 32 ayat (2), dan Pasal 38 ayat (2) UUPA, yang berisikan bahwa pendaftaran tanah menghasilkan surat tanda bukti yang berlaku sebagai alat pembuktian yang kuat. Berdasarkan ketentuan Pasal 32 ayat (1) PP No. 24 Tahun 1997, maka sistem publikasi pendaftaran tanah yang dianut adalah sistem publikasi negatif, yaitu sertifikat hanya merupakan surat tanda bukti yang mutlak. Hal ini berarti bahwa data fisik dan data yuridis yang tercantum dalam sertifikat mempunyai kekuatan hukum dan harus diterima hakim sebagai keterangan yang benar selama dan sepanjang tidak ada alat bukti lain yang membuktikan sebaliknya.

Dengan demikian, pengadilan yang berwenang memutuskan alat bukti mana yang benar dan apabila terbukti sertifikat tersebut tidak benar, maka diadakan perubahan dan pembetulan sebagaimana mestinya. Ketentuan Pasal 32 ayat (1) PP No. 24 Tahun 1997 mempunyai kelemahan, yaitu negara tidak menjamin kebenaran data fisik dan data yuridis yang disajikan dan tidak adanya jaminan bagi pemilik sertifikat dikarenakan sewaktu-sewaktu akan mendapatkan gugatan dari pihak lain yang merasa dirugikan atas diterbitkannya sertifikat.

Sertifikat hak atas tanah pada dasarnya mencerminkan Pendaftaran Tanah secara hukum (rechtkadaster atau legal cadastre) dalam hal ini pemberian tanda bukti hak kepada pemegang hak. Dalam konteks ini, maka fungsi sertifikat hak atas tanah adalah sebagai tanda bukti hak, yang diatur dalam ketentuan UUPA yaitu: Pasal 19 ayat (2) huruf c, bahwa sertifikat hak atas tanah adalah alat pembuktian yang kuat; Pasal 23 ayat (2), Pasal 32 ayat (2), dan Pasal 38 ayat (2).

Wujud konkret dari tujuan pendaftaran tanah dalam hal menjamin kepastian hukum dan kepastian hak adalah penerbitan sertifikat hak atas tanah. Sertifikat mempermudah pemegang hak untuk dapat membuktikan dirinya sebagai pemegang hak atas tanah yang bersangkutan. Berdasarkan ketentuan Pasal 19 ayat (2) UUPA, maka akibat hukum dari pendaftaran hak atas tanah berupa penerbitan surat tanda bukti (sertifikat) yang berlaku sebagai alat 
pembuktian yang kuat terhadap pemegang hak atas tanah.

Sertifikat hak atas tanah memberikan arti dan peranan penting bagi pemegang hak yang bersangkutan yaitu sebagai: Alat bukti kepemilikan atas tanah apabila ada sengketa terhadap tanah yang bersangkutan; Jaminan pelunasan suatu hutang pada Bank, Pemerintah atau swasta.

\section{Pembatalan Hak Atas Tanah}

Sertipikat sebagai tanda bukti hak bersifat kuat dan mutlak. Hal ini merupakan konsekuensi dari pemilihan stelsel negatif bertendensi positif dalam UUPA, oleh karena itu tidak tertutup kemungkinan pemegang hak dalam sertipikat hak atas tanah menghadapi gugatan pihak lain, yang merasa haknya terlanggar dengan terbitnya sertipikat tersebut, ke badan peradilan agar ia dapat memperoleh kembali haknya dengan menunjukkan bukti-bukti lain. Sasaran gugatan antara lain berupa tuntutan pembatalan atau tidak mempunyai kekuatan mengikat sertipikat tanah, pembatalan atau tidak mempunyai kekuatan mengikat peralihan atau balik nama sertipikat tanah atau pencabutan sertipikat tanah. ${ }^{11}$

Dalam UUPA, pembatalan hak atas tanah merupakan salah satu sebab hapusnya hak atas tanah tersebut. Apabila telah diterbitkan keputusan pembatalan hak atas tanah, baik karena ada cacat hukum administrasi maupun untuk melaksanakan putusan pengadilan, maka haknya demi hukum hapus dan status tanahnya menjadi tanah yang dikuasai oleh negara. ${ }^{12}$

Pembatalan hak atas tanah karena mengandung cacat administrasi dapat dilakukan karena permohonan yang berkepentingan atau oleh pejabat yang berwenang tanpa permohonan. Cacat administrasi ini meliputi: a. Kesalahan prosedur; b. Kesalahan penerapan peraturan perundangundangan; c. Kesalahan subjek hak; d. Kesalahan objek hak; e. Kesalahan jenis hak; f. Kesalahan perhitungan luas; g. terdapat tumpang tindih hak atas tanah; h. Data yuridis atau data fisik tidak benar; i. Kesalahan lainnya yang bersifat hukum administratif.

${ }^{11}$ Z.A Sangadji, Kompetensi Badan Peradilan Umum dan Peradilan Tata Usaha Negara dalam Gugatan Pembatalan Sertipikat Tanah, Citra Aditya Bakti, Bandung, 2003, h. 39.

${ }^{12}$ Mhd. Yamin Lubis dan Rahim Lubis, Hukum Pendaftaran Tanah, Mandar Maju, Bandung, 2008, h. 320.
Sedangkan pelaksanaan pembatalan hak atas tanah untuk melaksanakan putusan pengadilan yang telah memperoleh kekuatan hukum tetap harus melalui permohonan yang berkepentingan dengan melampirkan putusan pengadilan.

Dengan ilmu hukum dikenal ajaran mengenai kebatalan yaitu kebatalan mutlak atau absolute nietigheid dan kebatalan nisbi atau relatief nietigheid. Perbedaan kedua jenis kebatalan ini terkait dengan akibat yang dapat muncul dari hubungan hukum yang tercipta. ${ }^{13}$

Pengertian kebatalan mutlak dan kebatalan nisbi adalah sebagai berikut: Pertama, Kebatalan mutlak dari suatu perbuatan atau juga disebut dengan batal demi hukum. Suatu perbuatan hukum harus dianggap batal meskipun tidak ada pihak yang mengajukan pembatalan atau tidak perlu dituntut secara tegas. Perjanjian yang batal demi hukum harus dianggap perjanjian tersebut tidak pernah ada. Dalam lapangan hukum administrasi, suatu keputusan yang tidak memenuhi syarat sah keputusan Tata Usaha Negara maka keputusan demikian berakibat batal dan dianggap keputusan tersebut tidak pernah ada. Kedua, Kebatalan nisbi adalah kebatalan suatu perbuatan yang terjadi setelah dimintakan pembatalan oleh orang yang berkepentingan. Kebatalan ini mensyaratkan adanya tindakan aktif pihak yang berkepentingan untuk memohon pembatalan suatu hubungan hukum tertentu. Kebatalan nisbi dapat dibedakan menjadi 2 (dua) yaitu: a. Batal atas kekuatan sendiri atau nietig van rechswege, di mana kepada hakim dimintakan agar menyatakan batal atau nietigverklaard; b. Dapat dibatalkan atau vernietigbaar di mana hakim akan membatalkan, apabila terbukti suatu perbuatan hukum ditemukan adanya hal-hal yang menyebabkan kebatalan seperti adanya paksaan, kekeliruan, penipuan, dan lain-lain.

Ajaran kebatalan dalam konteks pemberian hak atas tanah menetukan status hak penguasaan atas tanah. Apabila ada permohonan pemberian hak atas tanah mengandung cacat yuridis yang bersifat subyektif maka sewaktu-waktu peristiwa yang melahirkan hak tersebut dapat digugat keabsahannya atau vernietigbaar. Bilamana dapat dibuktikan gugatan keabsahan suatu perbuatan hukum tersebut

${ }^{13}$ Hasan Basri Nata Menggala dan Sarjita, Pembatalan dan Kebatalan Hak Atas Tanah, Tugujogja Pustaka, Yogyakarta, 2005, h. 58. 
benar maka hakim akan memutuskan menyatakan betal hubungan hukum yang telah terjadi yang selanjutnya dapat dijadikan dasar untuk memohon pembatalan surat keputusan pemberian hak atas tanah dan/atau sertipikat hak atas tanah.

Mengenai kebatalan mutlak pada dasarnya juga dianut dalam Hukum Tanah Nasional. Hal ini ditunjukkan dalam PP No. 40 Tahun 1996 tentang Hak Guna Usaha, Hak Guna Bangunan, dan Hak Pakai Atas Tanah, yaitu dengan menggunakan istilah hapusnya hak karena hukum. Akibat hapusnya hak karena hukum maka hak atas tanah tersebut kembali kepada kondisi semula, misalnya Hak Guna Usaha menjadi Tanah Negara (Pasal 3 ayat (2)). Norma yang terkandung dalam Pasal 27, Pasal 34, dan Pasal 40 UUPA juga dapat dikatakan sebagai pelaksanaan prinsip ajaran kebatalan mutlak karena berakibat hapusnya hak atas tanah yang bersangkutan.

\section{Hapusnya Hak Atas Tanah}

Hapusnya hak atas tanah ini terdiri dari: Pertama, Hapusnya hak atas tanah dalam arti luas. Merupakan berakhirnya tanggung jawab negara terhadap hak atas tanah terdaftar di kantor pertanahan dengan atau tanpa kemauan pemegangnya, baik berdasarkan ketetapan konstitutif atau deklaratoir, sesuai dengan Pasal 18, Pasal 21, Pasal 27, Pasal 34, dan Pasal 40 UUPA yaitu: Karena dicabut untuk kepentingan umum; Karena prinsip nasionalitas; Karena penyerahan atau pelepasan dengan sukarela oleh pemiliknya; Karena ditelantarkan; Karena peralihan hak akibat peristiwa hukum seperti testament dan ab intestat; Karena peralihan hak akibat perbuatan hukum seperti jual beli, tukar menukar, hibah, dan lain-lain sesuai peraturan perundang-undangan; Karena tanahnya musnah; Karena jangka waktunya berakhir; Karena syarat tidak dipenuhinya oleh pemiliknya.

Kedua, Hapusnya hak atas tanah dalam arti sempit. Merupakan berakhirnya tanggung jawab negara terhadap hak atas tanah yang terdaftar di Kantor Pertanahan tanpa kemauan pemegangnya baik yang berdasarkan ketetapan konstitutif atau deklaratoir yang oleh kepala kantor pertanahan dilaksanakan pencatatan di buku tanah dan di surat ukur bersangkutan, yaitu: Hapusnya hak atas tanah karena dibatalkan berdasarkan putusan pengadilan; Hapusnya hak atas tanah karena dicabut kepentingan umum; Hapusnya hak atas tanah karena tanahnya musnah akibat bencana alam.

\section{PENUTUP \\ Kesimpulan}

Bahwa ratio legis diberlakukannya peraturan pemerintah mengenai larangan kepemilikan tanah absentee di Indonesia didasarkan pada:

Pertama, Asas efektivitas, baik terhadap penyelenggaraannya, pengawasannya, atau pengangkutan hasilnya, Sehubungan dengan itu pemilik tanah itu perlu bertempat tinggal di kecamatan letak tanah tersebut, agar tanah itu dapat dikerjakan sendiri, sesuai dengan prinsip bahwa tanah adalah untuk tani yang menggarapnya.

Kedua, Asas keadilan, karena para petani yang memeras keringat dan mengeluarkan tenaga hanya mendapat sebagian saja dari hasil tanah yang dikerjakan, sedangkan pemilik tanah yang tinggal di kota-kota (sebagian besar sudah mempunyai mata pencaharian lain) dengan tidak perlu mengerjakan tanahnya mendapat bagian dari hasil tanahnya pula.

Ketiga, Larangan kepemilikan tanah absentee adalah merupakan salah satu faktor penyebab hilangnya hak waris, seperti yang tertuang dalam Pasal 3c PP No. 41 Tahun 1964, sehingga dalam jangka waktu 1 tahun sejak si pewaris meninggal dunia, ahli waris diwajibkan memindahkan hak atas tanah tersebut kepada orang lain yang tinggal di kecamatan di mana tanah tersebut berada atau ia wajib untuk pindah ke kecamatan letak tanah tersebut. Jangka waktu tersebut dapat diperpanjang oleh Menteri Agraria apabila terdapat alasan yang wajar. Apabila kewajiban ini tidak dilaksanakan maka tanah pertanian itu akan diambil pemerintah dan selanjutnya dibagikan kepada para petani yang belum memiliki tanah pertanian.

\section{Rekomendasi}

Berhubungan erat dengan kesimpulan di atas, maka disarankan: Pertama, Dasar diberlakukannya peraturan pemerintah mengenai larangan kepemilikan tanah absentee di Indonesia sudah tidak lagi sesuai karena: a. Ketentuan-ketentuan larangan kepemilikan tanah absentee yang ada pada saat ini masih perlu ditinjau kembali untuk disesuaikan dengan perkembangan zaman karena dianggap sudah terlalu usang, padahal akses sarana transportasi 
dan prasarana lainnya sudah mengalami banyak kemajuan, sedangkan aturan mengenai kepemilikan tanah absentee tidak ada perubahan sejak dulu; $\mathrm{b}$. Ketakutan pemerintah mengenai keadilan seharusnya tidak lagi menjadi persoalan, karena sudah banyak peraturan perundang-undangan yang dengan tegas melindungi hak-hak pekerja, termasuk yang aturan mengenai upah, jam kerja, dan lain-lain.

Kedua, Berbagai peraturan perundang-undangan sebagaimana yang telah kita bahas tersebut di atas nampak sama sekali tidak memiliki dasar hukum maupun dasar rasional, bahkan nampak bertentangan dengan pikiran wajar kita atau common sense. Jelas peraturan mengenai kepemilikan tanah absentee sangat bersifat politis, yakni keinginan untuk menguasai tanah oleh para penguasa, karena ahli waris yang seharusnya memiliki hak penuh atas obyek waris yang mungkin saja sudah turun temurun harus dipaksa untuk melepaskan haknya kepada orang lain. Sehingga menurut penulis perlu adanya pembaharuan hukum yang mengatur lebih rinci mengenai masalah tersebut.

\section{DAFTAR PUSTAKA}

\section{Peraturan Perundang-undangan:}

Undang-Undang Nomor 5 Tahun 1960 tentang Peraturan Dasar Pokok-Pokok Agraria.

Peraturan Pemerintah Nomor 10 Tahun 1961 tentang Pendaftaran Tanah.

Peraturan Pemerintah Nomor 224 Tahun 1961 tentang Pelaksanaan Pembagian Tanah dan Pemberian Ganti Kerugian.

Peraturan Pemerintah Nomor 41 Tahun 1964 tentang Perubahan dan Tambahan Peraturan Pemerintah No. 224 Tahun 1961 tentang Pelaksanaan Pembagian Tanah dan Pemberian Ganti Kerugian.
Peraturan Pemerintah Nomor 40 Tahun 1996 tentang Hak Guna Usaha, Hak Guna Bangunan, dan Hak Pakai Atas Tanah.

Peraturan Pemerintah Nomor 24 Tahun 1997 tentang Pendaftaran Tanah.

\section{Buku:}

Harsono, Boedi, 2008, Hukum Agraria Indonesia (Sejarah Pembentukan Undang-Undang Pokok Agraria, Isi dan Pelaksanaannya), Jakarta: Djambatan.

Limbong, Bernhard, 2014, Opini Kebijakan Agraria, Cetakan ke-1, Jakarta: Margaretha Pustaka.

Lubis, Mhd. Yamin dan Rahim Lubis, 2008, Hukum Pendaftaran Tanah, Bandung: Mandar Maju.

Marzuki, Peter Mahmud, 2012, Pengantar Ilmu Hukum, Jakarta: Kencana Prenada Media Group. Menggala, Hasan Basri Nata dan Sarjita, 2005, Pembatalan dan Kebatalan Hak Atas Tanah, Yogyakarta: Tugujogja Pustaka.

Sangadji, Z. A., 2003, Kompetensi Badan Peradilan Umum dan Peradilan Tata Usaha Negara dalam Gugatan Pembatalan Sertipikat Tanah, Bandung: Citra Aditya Bakti.

Santoso, Urip, 2010, Pendaftaran dan Peralihan Hak Atas Tanah, Jakarta: Kencana Prenada Media Group.

Seto, Bayu, 2001, Dasar-Dasar Hukum Perdata Internasional, Cet. III, Bandung: Citra Aditya Bhakti.

Soeprapto, R., 1986, Undang-Undang Pokok Agraria dalam Praktek, Yogyakarta: Badan Pertanahan Nasional.

Supriadi, 2007, Hukum Agraria, Jakarta: Sinar Grafika.

Tanuwidjaja, Henny, 2012, Hukum Waris Menurut $B W$, Cet. I., Bandung: Refika Aditama. 